\title{
INCREASING POTENTIAL OF DISTRIBUTION CHANNELS FOR CREATIVE THAI HAND-WOVEN TEXTILE PRODUCTS IN THE DIGITAL ECONOMY
}

\author{
Supaporn CHAI-ARAYALERT (1D ${ }^{1, *}$, Ketsaraporn SUTTAPONG ${ }^{2}$ \\ ${ }^{1}$ Prince of Songkla University, Faculty of Science and Industrial Technology, Department of Applied \\ Mathematics and Information Systems, Surat Thani 84000, Thailand \\ ${ }^{2}$ Prince of Songkla University, Faculty of Liberal Arts and Management Sciences, Department of \\ Managementm, Surat Thani 84000, Thailand
}

Received 5 January 2020; accepted 23 July 2020

\begin{abstract}
The research was to investigate the omni-channel distribution system for the weaving community enterprises. This research was qualitative, utilizing a case study approach. The results identify the limitations of selling creative products only through physical stores, which are unable to respond to customers' purchasing behaviors and needs. Nevertheless, the online channel alone cannot communicate the delicacy of handmade woven products through digital media since they need to be touched and worn to be fully appreciated. This dichotomy led to the design and development of the first version of the system. The research encourages the weaving community enterprises to widen their market in order to be able to compete in digital economy. It provides valuable practical insights into local weaving community enterprises and their ability to market their creative products in the digital era. This research fills a gap in the literature relating to the customer journey and the integration of distribution channels and sheds light on the need for local weaving community enterprises to adapt to the current market conditions.
\end{abstract}

Keywords: community enterprise, creative product, customer journey, distribution channel, hand-woven textile, omni-channel strategy.

\section{Introduction}

The increasing number of digitally literate consumers has created fast-growing demand for businesses and the number of Internet users has grown rapidly because of significant technological advances. In the Association of Southeast Asian Nations region, people below the age of 30 represent $40 \%$ of the total of 640 million consumers. They are digitally literate and represent a huge capacity for building the region's digital economy in the future (Thailand Board of Investment, 2018). This strong position is based on the high degree of Internet and mobile-phone penetration within Thai society. As a result, the value of Thai e-commerce

*Corresponding author. E-mail: supaporn.chai@psu.ac.th 
in 2017 was 2.76 trillion baht, representing an increase of $91.7 \%$ from 2016, of which with business-to-customer for 70.5 trillion baht (47.27\% of market) (Depa, 2017). However, the basic digital technology ability and performance of small businesses and community enterprises (CEs) with less than 10 employees in Thailand is not good compared to large and medium-sized businesses (Depa, 2017), and the business operations of such enterprises are typified by traditional processes and less innovative development of products and services. Therefore, they find it difficult to respond to customers' behaviors based on digital-technological advances.

The research reported in this paper was conducted to study CEs that produce and sell traditonal hand-woven textiles, which represent the cultural heritage of each region (ChaiArayalert \& Suttapong, 2018; Patichol et al., 2014). Traditonal hand-woven textiles are channels for cultural representation and creative expression. These products are in great demand in global markets because of their distinctive patterns and colors, and the use of natural raw materials. The value of handicrafts, textiles and clothing exported from Thailand has been growing continuously and in 2017 amounted to approximately 9282 million baht (Industry Network, Thailand Textile Institute, 2017). The Thai government needs to adopt means to improve CEs and enhance their capability through applied innovation and digital technology.

The enhancement of local weaving CEs is based on the quality of products which need to be brought into line with demand from the global market through the employment of innovation, technology and creativity (Industry Network, Thailand Textile Institute, 2017). In this way, value can be added to products by differentiating them from their competitor products. As far as distribution channels are concerned, CEs must adapt their own businesses in order to keep pace with advanced digital technologies as well as consumer behaviors. Therefore, in addition to traditional distribution channels, some CEs have been using online media to operate their businesses. The means of distribution has thus changed from single-channel to multi-channel although there may be some limitations on the independence of the various channels, including difficulty in managing information, and the need for consistency in every distribution channel (Fayaz \& Azizinia, 2016; Ishfaq et al., 2016). These difficulties may also affect consumers' purchasing experience through each channel, and this may lead to complications which can cause operational difficulties for enterprises as well as higher costs. Therefore, it is essential that the development of digital plateform should integrate all aspects of business performance to ensure that enterprises achieve maximal efficiency.

The needs outlined above informed the research objective of this study, the aim of which was to enable local handicraft producers to widen their market in order to compete in digital economy. The aim of utilizing digital technology is to increase efficiency, reduce costs and transform the pattern of trading from a traditional style to one mediated through online resources.

This study contributes in a significant way to in-depth study traditional weaving CEs in Southern Thailand and introduces the omni-channel digital plateform to the traditional weaving producers. This plateform is applied to the real-world setting in the weaving communities to enabling a system implementation and improving the competitiveness of CEs.

This paper begins with a review of literature which firstly aims to elucidate the characteristics of Thai weaving CEs and the limitations entailed in their current operations. This 
is followed by an explanation of the concept of the customer journey and how customers' behaviors are being transformed by technology, and an examination of the evolution of the concept of the omni-channel strategy. The sections which follow deal with the research framework and methodology, the results of the study, and discussion and conclusions.

\section{Thai weaving community enterprises as creative communities}

Creative industries in Thailand are driven by knowledge, culture and local wisdoms. Thailand has shifted the focus to the knowledge and creativity-based production (Bhatiasevi \& Dutot, 2014; Parivudhiphongs, 2019). Creative industries have a significant contribution to the economy, because it can create a positive business climate, strengthen the identity, support the utilization of local resources, and have a positive social impact (Boccella \& Salerno, 2016; Wuwei, 2011). The term of creative industries include the cultural industries combine with all cultural or artistic production (Boccella \& Salerno, 2016; Rossi, 2016). The creative industries are those in which the product or service contains a substantial element of artistic or creative endeavor (Boccella \& Salerno, 2016; Wuwei, 2011).

Thai weaving CEs represent as creative communities that refer to social relations in certain regions and reflect a necessary sociality related to the development of creative industries. The main characteristic of local weaving CEs is that they are community activities related to the weaving of local products organized by a group of weavers whose members commit to and share their way of life and perform weaving activities communally in order to earn a living and create community self-independence (Distanont et al., 2019; Wechakama, 2011). Thai hand-weaving CEs are important and interesting as a sector of the creative industries in Thailand. They are used as a tool for economic development by bringing the culture which reflected the local life and livelihood to create commercial and cultural products. Creativity in the Thai weaving (illustrated in Figure 1) include the entire range of handmade products produced by CEs, which display both refinement and beauty. Thai hand-woven textiles are not only tangible objects but also represent valuable items produced based on local culture and knowledge which have both aesthetic and financial value. Cultural products such as Thai traditional textiles are able to generate local economic growth and sustainability.

Previous research has found a number of limitations in the means traditionally adopted in marketing the products of local weaving CEs (Fayaz \& Azizinia, 2016; Herhausen et al., 2015; Kluge \& Fassnacht, 2015; Patichol et al., 2014; Menon Vadakepat \& Al Khateeb, 2012). The distribution channels are rather limited and traditionally, only physical distribution channels were employed. The existing distribution channels do not facilitate market expansion since customers may lack access to market information (Menon Vadakepat \& Al Khateeb, 2012; Wongleedee, 2015). The enlargement of the customer base has also been difficult because adaptation to the use of online media has been slow. As noted above, information is nowadays mostly accessed directly or by telephone or through social media and this is somewhat restrictive since it tends to limit customers mainly to those who live around the store or who may happen to visit stores. Thus it is difficult to extend the customer base without incurring some form of technology cost and having the requisite technical skills. Specifically, there is no system which jointly utilizes data from multiple distribution channels, which can lead to 

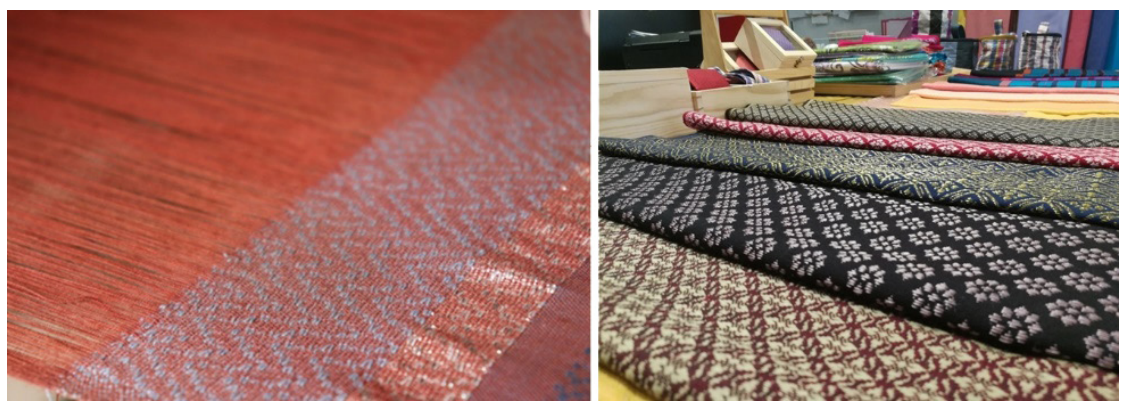

Figure 1. The hand-woven products from Ban Nernmuang Weaving Group (source: created by authors)

inaccurate and inconsistent data being presented through different sources. CEs have been facing a situation where technology is disrupting their business, that is, they encounter the problem of selling traditional products in a contracting market and need to transform their output to be consistent with modern society and lifestyles. Thus, it is essential to address these issues and to enhance their competitive position by meeting consumer demands both in terms of the products they produce and the means by which they are made available to the market through digital technology.

The following section of this literature review therefore deals with the issue of the customer purchase decision and examines the significance of an omni-channel strategy, and this will be followed by the development of the research framework.

\section{Customer journey}

The customer journey starts by creating purchasing motives and grabbing the customers' attention and then proceeds to the customer buying the products or services offered, and is followed by product and service development to respond to customers' needs. Finally, businesses must efficiently create post-sales satisfaction to ensure the on-going success of their business activity (Følstad \& Kvale, 2018; Stein \& Ramaseshan, 2016).

The journey is comprised of awareness, consideration, purchase, retention, and advocacy (Lemon \& Verhoef, 2016; Wolny \& Charoensuksai, 2014). Awareness aims to make customers aware of products and services. It is comprised of all the activities undertaken to reach the target customers through a variety of communication media. Each medium is able to offer a variety of content and offers varying frequency of reaching customers (Marquez et al., 2015; McColl-Kennedy et al., 2015). The next stage, consideration, arises when consumers research product data prior to making a purchase decision (Karimi et al., 2014; Rosenbaum et al., 2017).

The purchase phase can be performed directly at physical stores or through online stores and may entail different delivery methods (Karimi et al., 2014; Rosenbaum et al., 2017). If customers are happy with the stage, they conduct the next step of the journey, retention, which is the creation of customers' loyalty, that is, if the customers are impressed with the products they will purchase them again. It is crucial for a business to manage its relationship 
with its customers while providing a satisfactory experience so that they will continue to buy its products. Activities undertaken to this end naturally lead to the next step of the customer journey, advocacy, which occurs when customers have been impressed by what they have purchased and want to support those products and share their experience with others (Rosenbaum et al., 2017; Vivek et al., 2012). Good experience thus leads to preference, loyalty, and advocacy and the customer journey approach was employed in this study to analyse, design and implement a system that matches customers' needs while also supporting a seamless customer experience derived from the joint operation of various distribution channels.

\section{Paradigm shift in digital distribution channels of creative products}

The distribution channel adopted affects the characteristics of the products made available to the consumer and the processes by which they are made available. The basic distribution channel is a single-channel activity where consumers purchase goods from a single outlet (Ailawadi \& Farris, 2017; Gallino \& Moreno, 2014). A multi-channel system consists of more than one distribution channel and will include both online and offline channels (Blázquez, 2014; Dholakia et al., 2010; Neslin \& Shankar, 2009). However, the different channels are not directly connected or coordinated and are conducted separately. Across-channel system is similar to a multi-channel system, but entails opportunities for connecting the different channels together (Beck \& Rygl, 2015; Piotrowicz \& Cuthbertson, 2014). However, each channel independently manages its own system and information.

A new method has emerged to improve cross-channel operations called the omni-channel strategy, which focuses on consumers and ensures that they receive the best experience on their purchasing journey through the collaboration of various distribution channels (Beck \& Rygl, 2015; Herhausen et al., 2015). Digital technology is employed in omni-channel management, which can accommodate expansion beyond purely purchasing. For instance, consumers can select a product on a website, try it at a physical store, purchase and receive the product at a branch of the store with a stock of the product, or, after trying it at the physical store, order the product from an online store. Sellers are able to record consumers' data from all channels in order to analyse, plan and produce products to meet their requirements and, in addition, are also able to offer suitable promotion and advertising based on customers' purchasing behavior at every distribution channel.

It can be said that the omni-channel strategy is a development of the cross-channel system achieved by connecting the data and the operation of distribution channels into one overall system, which aims to respond to customers' needs and offer customers a satisfying experience throughout the entire purchase decision process. Moreover, the customer data collected can be used to analyse their purchasing behavior, which might enable suppliers to offer other products, thus increasing sales opportunities as well as creating a good impression with customers (Huré et al., 2017; Mirsch et al., 2016). The omni-channel strategy is, therefore, a combination of sales channels which on the one hand aims to create a new experience incorporating benefits for customers' including comfort and enjoyment in the purchasing. On the other hand, the benefits for sellers include access to more customers 
through the various distribution channels, easy access to customers and convenience in every distribution channel, with information relating to products, customers and sales promotion being constantly correct and up-to-date. Additionally sellers have more distribution channels through which they can respond to buyers' behaviors and more efficient communication among different distribution channels (Gallino \& Moreno, 2014; Hübner et al., 2016; PicotCoupey et al., 2016).

The omni-channel strategy is also able to expand the capacity of existing channels since it systematically connects information from distribution channels and caters to consumers' needs, which are constantly changing, from the pre-purchase stage through to receiving the product, as well as offering post-sales service. By employing digital technology, business efficiency is increased and business operations supported in a constantly changing market. Distribution strategy can be changed from a single channel to omni-channel by combining existing physical stores with other channels with the aim being to upgrade consumers' purchasing experience into a seamless customer purchase journey managed by a single database, thus building customer relationships in every distribution channel and allowing customers to encounter familiar experiences in while making their purchases.

The next section presents the research framework adopted in this study based on the concept of a customer journey for local hand-woven products, which, while different from other those for other products, integrates the omni-channel strategy of distribution as well as other relevant concepts leading to the design and development of a bespoke system for the marketing and sale of local hand-woven products.

\section{Research framework}

Most businesses in digital economy adopt more than one distribution channel through a multi-channel strategy in order to respond to customer behaviors. Some previous studies (Blázquez, 2014; Lewis et al., 2014; Pantano \& Viassone, 2015) have revealed that a problem with the multi-channel strategy is that it can be affected by customers' ability to purchase from many different outlets, Thus if the purchasing situations and conditions are varied between each outlet then the buyer may become confused and feel that the stores and hence the suppliers themselves are unreliable. This may happen because of inconsistency in product information relating to products obtained through different channels, and difficulty in managing a product inventory and inspection. In addition, customer data is not combined between channels and data relating to product purchases may not be accurate in each distribution channel because of the lack of integration of data between channels, since each distribution channel operates independently (Gallino \& Moreno, 2014; Zhang et al., 2018). For this reason, the omni-channel strategy has been introduced to manage the need for the integration of distribution channels and points of customer contact with the aim of offering customers a better purchasing experience (Cook, 2014; Lemon \& Verhoef, 2016; Stein \& Ramaseshan, 2016).

The research framework shown in Figure 2, the system focuses on transactions between sellers and buyers which are seamlessly connected in an omni-channel environment. This system integrates various distribution channels under a central database, by employing digi- 


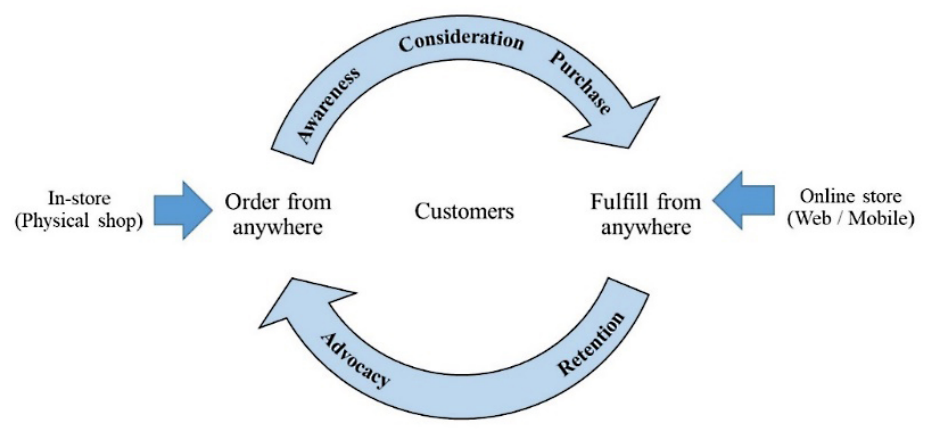

Figure 2. Research framework (source: created by authors)

tal technology. This system, provides a comprehensive framework incorporating different distribution channels including in-store and online-store shopping. In-store shopping is the traditional channel through which customers buy hand-woven fabrics which differ from other products since the selection process requires the use of the human senses, such as sight for looking at raw materials and the hands for touching the fabric and trying the garment on to judge its aesthetic appeal based on the purchasers' emotions. The greatest chance of achieving a closed sale is, therefore, through the in-store selling channel (Wade Clarke et al., 2012; Spence et al., 2014).

Nevertheless, e-commerce offers easy and convenient access to product information and enables prospective customers to conduct price comparisons, and to select and purchase such products. The system also incorporates a section on the website aimed at developing and maintaining customer relations by allowing them to record their opinions and suggestions, and to review the products they purchase. The system is thus organized in a manner which makes it easy for consumers to make purchase decisions (Jeffers \& Nault, 2011; Parker \& Weber, 2013). The technology used to support brick-and-click commerce is expanded from directly physical stores to enable purchases to be made via online transactions, which are managed simultaneously with the mobile shopping site distribution channel and suppliers are thus able to reach a wider range of consumers, who are able to access information, or buy products anywhere and anytime (Hansen \& Tambo, 2011; Lazaris et al., 2015; Magrath \& McCormick, 2013).

In developing the proposed system based on an omni-channel approach, a number of aspects were taken into consideration. Firstly, the system integrates physical and online distribution channels and for consumers' convenience allows channel switching during a purchasing transaction. Secondly, the integrated data relating to distribution channels allows analysis based on products, customers, order transactions, promotions, and made-to-order transactions. Moreover, the database system integrates every distribution channel and incorporates comprehensive and up-to-date data which is processed and can be analysed in real time. Finally, the system allows integrated communication between distribution channels, achieved by deploying information and communication technology, which also facilitates efficient communication with consumers. 
Based on the research framework, the system was designed and developed to accommodate customers' purchase decision behaviors based on the concept of the consumer journey through all phases of purchasing products from pre-to-post purchase. Additionally, the system offers easy access to product information, based on which potential customers can decide whether or not to buy a product and allow them to choose whichever distribution channel they find most suitable for their needs. Lastly, the system recognizes that with the increasing use of the internet, online media plays a vital role in the making of purchase decisions.

\section{Research methodology}

The qualitative research by case study was employed, focusing on the Ban Nernmuang Weaving Group (BNWG), a CE in Nakhon Si Thammarat province in Southern Thailand. This selection of case study is based on unique local knowledge transmitted and maintained through its members with the operation having been carried on over 34 years until the present.

Data were collected from the CE leader, its members, and selected customers. The collection methods, consisted of in-depth interviews and observations followed by an evaluation of the data collected based on inspection by experts and professional weavers. The data collected were analysed through the software development methodology (Brereton et al., 2007; Jabangwe et al., 2018) with the following steps.

Problem recognition was conducted to gather operational data from the weaving group through reviewing documents, interviews, and observation of business operations.

System analysis was conducted to determine the functional and non-functional requirements. The functional requirements were based on the concept of the customer journey which is comprised of

a) Pre-purchase: this stage is about raising awareness. Customers are motivated to notice and purchase products both online and offline and a major requirement of the system is to offer detailed product information. This would include sales staff offering advice in stores or other sources of in-store information, online searching tools, online product catalogues, product comparison tools, and previous customers' comments, and reviews;

b) Purchase: this takes place when customers have located products online and proceed to a store to view or try on the products prior to purchase. This is followed by an order process function and then a payment function which can be through a physical store, shopping website, or mobile shopping site. The final function is delivery which can be either at a store or product delivery point, or by home delivery;

c) Post-purchase: this is when customers use the product and are satisfied with it. They perform the next two functions relating to retention and advocacy, such as rating the product, sharing experience.

The design of the back-end system consisted of the database design based on a relational model. Meanwhile, the front-end system was largely concerned with the design of the user interface, which aimed to be responsive to all distribution channels, with the focus on the buyers' experience through the look and feel of the system, projected an impression of the 
hand-woven fabrics of Southern Thailand, which it was expected would attract buyers and create more sales opportunities. In addition, the user interface offered a consistent approach for all distribution channels in terms of how the user connected with it, the aim being to project a conducive atmosphere to purchasing unique local products as well as a brandspecific design concept. Upon completion of the development and testing, it was evaluated by members of the target users' groups to assess their satisfaction with it.

\section{Results}

\subsection{Omni-channel system for Thai weaving community enterprises}

Based on the research objective and framework, the omni-channel system was developed to perform its functions for in-store, web site and mobile site shopping (shown in Figure 3).

In front-end system, the customers are able to use the system in various distribution channels, for each of which the functional design offers the same features. This is consistent with the concept of the customer journey: pre-purchase, purchase, and post-purchase. For instance, the customer can search for information, read product reviews, or examine a purchasing list. At the same time, to be useable, a design must have features which are in line with the distribution channels and must be easy to learn and use and importantly, must detect and clearly notify errors. Moreover, the system must be designed to create distinct product recognition with easy access to relevant product information while stimulating customers to make a quick purchase decision as well as encouraging them to return and also to give word-of-mouth recommendations to other potential customers. The system was developed based on the customer journey as follows.

Product awareness was created by offering information and through functions, such as offering new products and highlighting best-sale products, providing information online and in-store, and advertisements. This phase helps to convert visitors into customers. It encourages the emotional experience for visitors, for example recognize and respond to emotion in online store visitors, engage and convince with persuasive storytelling, and enhance positive

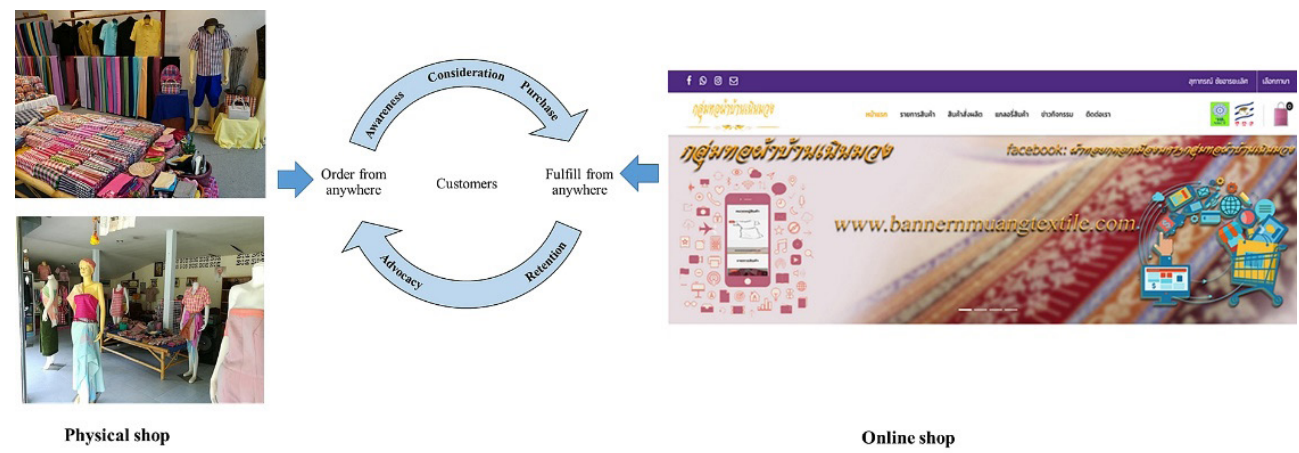

Figure 3. Omni-channel system for Thai weaving community enterprises (source: created by authors) 
emotions with visitors. The system was developed to allow customers to have convenient access and to be able to search via every channel, for instance, by direct enquiry to the store, online searching or using product reviews.

Customer attention which might be based on product information from stores or advertising media. However, for this research, the information was obtained from different distribution channels so that the customer was in possession of sufficient details to make a purchase decision quickly and conveniently. The supporting functions in the system comprise: online catalogues, product comparison tool, online searching and browsing, product tagging to make searching easier, and viewing comments and reviews from others. When customers search online, they may still want to actually see and touch the products, so they can visit a store to experience the real thing, and once in the store, they can use their mobile phone to compare the product choices.

Purchase may be conducted either online or in a physical store. The relevant system functions consist of order management, payment, delivery, product customization and customer services, for which the system connects both online and offline channels. The customer can choose their preferred methods of payment, delivery, or returning products (click and delivery or click and collect or buying at a store and delivery).

Retention occurs if the customer is satisfied with the product, the functions developed include updating the favorite list recorded in the user's account to show their purchase as a preferred product or requesting that they review the product, and managing member accounts in order to contact and communicate with them, for instance, when promoting a new product. The retention of purchasing data also helps the business to understand customers' behaviors which can contribute to future promotional plans.

Advocacy is the final step where customers show and share their experience. The functions designed include clicking the like and share to friends buttons or reviewing, comment on, and rating products. It includes post-purchase review functions through social media platform, such as Facebook, for more reputation building approach.

The back-end system supports, for example, through dedicated customer, product, inventory, transaction, and security modules. In addition, the system provides a dashboard which presents the operational reports of all distribution channels. The system is developed to monitor and respond to customers' behaviors which transform according to technological advances and that is why the customer journey was employed as the guiding principle in designing and implementing the system.

To examine the omni-channel system, there are different levels during the process of testing. The black-box testing was selected as technique of software unit testing and followed by testing the system as a whole. The next section is the system evaluation which is a systematic and experimentally based gathering of information about a software using user representatives.

\subsection{System evaluation}

The system's efficiency was evaluated by 40 participants, consisting of the leader, its members, and selected customers. The evaluation was divided into customer journey phases: pre-purchase, purchase, and post-purchase and details of the outcome of the assessment. The overall 
results revealed that the users were satisfied with the efficiency of the system at a high level $(\overline{\mathrm{x}}=4.19)$, and the following are the detailed results.

For system efficiency at the pre-purchase phase where the evaluation was based on the interface, navigation, and content (Hasan et al., 2013; Huang \& Benyoucef, 2017), which are the main components of awareness satisfaction of at a high level $(\overline{\mathrm{x}}=4.29)$, with the three highest scoring features being that the domain name was easy to remember and consistent with the CE name, that in the design of the homepage the product information fulfilled consumers' requirements and that navigation within the system was effective and easy to use.

The efficiency evaluation at the purchase phase, which covers purchasing activities through each of the distribution channels focused on two important points: functionality and reliability (Hasan et al., 2013; Stefani \& Xenos, 2011). The result was also at a high level ( $\overline{\mathrm{x}}=$ 4.26) and the highest ratings given were for the clear description of how to order, payment and deliver and that the purchasing system is clear and easy-to-understand, with equal ratings being for the features of the system dealing with warranty and privacy policy, the shopping cart system, ordering confirmation and the payment system. The users also agreed that the system had suitable tools for identifying product categories, searching and browsing for products, and comparing products, and that there were adequate methods of payment provided, all of which aspects were given equal approval rating scores.

The post-purchase phase allows customers to comment on products they buy and to share their product experiences in order to facilitate and manage the enterprise's relationship with customers and to encourage customers to make future purchases and to communicate their experience to others. The evaluation of this phase focused on how well the system dealt with encouraging existing or future customers to enter the community of product users by supporting their purchase journey (Hasan et al., 2013; Huang \& Benyoucef, 2017). The result of this assessment was at the high level $(\overline{\mathrm{x}}=4.12)$ and the three highest rated features on the list were: (a) suggestions on product lists/promotions allowing the online society or community to exchange ideas; (b) customers' product reviews; (c) advocacy from previous buyers/services through reviews or comments from customers to strengthen the producers reputation as a reliable supplier, together with social features including, favorite shopping list, share, like, rate, and feedback. Therefore, the users were satisfied with the social function of the system which is committed to creating customer loyalty and supporting the brand or product.

In the evaluation of the technical efficiency of the system, the results were at a high level $(\overline{\mathrm{x}}=4.10)$ and the three highest ranked features were: (a) the ability to purchase from more than one distribution channel (physical store, website, and mobile app), and the system's ability to support different screen-size devices; (b) compared to traditional channels, users have multiple ways to easily communicate with the store; (c) the systems security relating to payment transactions.

Therefore, the results revealed that the participants rated the systems' efficiency highly in all three phases of the purchasing journey, pre-purchase (in terms of the design of the user interface, the organization of the content, and navigation), purchase (in terms of making purchasing reliable and providing functional tools), post-purchase (in terms of designing features for customer connection and community), and that they also rated the technical efficiency of the system at a high level. 


\section{Discussion}

Thai weaving CEs are face various limitations, notably, inefficiency in managing information, being unable to provide continuously available staff and service, being incapable of conducting wide ranging product promotion and marketing, and selling their creative products only through the in-store channel. The inconvenience arises which leads to enterprises being unable to effectively respond to consumers' needs, and to compete with other businesses, as well as difficulty in coping with rapid changes and trends in consumers' behaviors and preferences (Chai-Arayalert \& Suttapong, 2018; Cook, 2014). In order to deal with these limitations, some CEs have begun to develop their distribution channels to encompass online shopping.

In the case study conducted in this research, distribution of these creative products requires different methods from those of mass-produced goods with which consumers are familiar as well as being familiar with their distribution methods. Employing the online channel and digital media alone may not be sufficient to allow potential customers to experience the creativity in woven products with their own senses and to allow their emotional responses to come into play, especially where handicrafts are produced with high quality raw material. It is impossible to feel the quality or delicacy of beautifully woven garments through digital media.

The abovementioned problems have commanded the attention of some researchers, for example, (Fayaz \& Azizinia, 2016; Herhausen et al., 2015; Kluge \& Fassnacht, 2015; Patichol et al., 2014; Menon Vadakepat \& Al Khateeb, 2012), who studied the challenges of different distribution channels for creative products with special features, including how these are affected by changes in consumers' behaviors due to advances in digital technology. Moreover, garments made from hand-woven fabrics need to be touched and tried on by the customer before any purchasing decision is made.

This research found that the growth of online business for CEs is still slow because while the online channel is unable to effectively respond to consumers' needs, the traditional method of selling their products is no longer in tune with many peoples preferred ways of selecting and purchasing products. Therefore, today, many product markets have adapted to the modern zeitgeist through the adoption of a multi-distribution-channel approach, for instance, by selling products through community in-store sales, online stores and mobile shopping sites. As found in previous research, although the multi-distribution-channel approach reduces the limitations inherent in the use of a single distribution channel, other limitations still exist, such as the independence of the data and operations of the different channels and the lack of integrating between distribution channels, which, together, affect the services provided to consumers (Blázquez, 2014; Cook, 2014; Jeffers \& Nault, 2011; Pantano \& Viassone, 2015). In view of the situation outlined above, this research aimed to build an integrated system that would connect different distribution channels including physical stores which provide potential buyers with the ability to touch and try on woven garments prior to purchase. The system developed is able to connect existing distribution channels in order to create a seamless purchasing experience or omni-channel. It has been noted that, today, omni-channel approaches are more prevalent in influencing business transactions. However, employing such an omni-channel approach to local weaving CEs represents a considerable challenge even though the optimal strategy for the hand-woven fabric distribution might appear to be one of linking all online and offline distribution channels together. The develop- 
ment of this omni-channel system has the opportunity to create a purchasing experience that can connect all distribution channels and thus respond to the rapid evolution of consumers' behaviors due to advances in technology and can also bring sorely needed adjustments to the business model widely employed by Thai weaving CEs which if they are to survive and prosper in the future need to be conducted immediately.

\section{Conclusions}

The omni-channel system for Thai weaving CEs was designed and implemented in a case study of the BNWG, Nakhon Si Thammarat province. The research aimed to encourage producers of hand-woven textiles to widen the scope of their distribution channels in order to be able to compete in the world market. The results suggest that the system developed will increase selling opportunities through market expansion, from the local and regional scale to a global scale, through online channels. The system was designed to integrate the in-store, website, and mobile channels and to collect data from all channels to improve both the suppliers' knowledge of their market as well as the customers' purchasing experience, adopting as its guiding concept the customer journey.

The aims in designing the system were to expand the capability of the existing distribution channels to serve the needs of customers in the modern era by connecting together various groups of consumers. The omni-channel approach adopted is able to integrate various distribution channels into one integrated system which will support customer journey, from the prepurchase to post-purchase phases including offering after-purchasing services. The transformation from a single-channel to an omni-channel strategy will connect existing physical stores with other distribution channels made possible by advances in digital technology.

The results are considered to be an important initial step which can enhance their capacity to offer their products through a variety of distribution channels. However, there are some limitations to this research and its findings. First, this study aimed at developing the distribution capacity of a specific group consisting of weaving CEs in Southern Thailand, and the system was focused on the needs and features of this special group. Therefore, other groups of similar products may not be able to effectively employ this system developed in this study. Second, there are limitations inherent in the technology and operational costs entailed in using the system and the level of technological readiness in CEs such as that studied may pose a limitation to the adoption of the system. Moreover, the system did not include marketing channels employing social media, therefore, future research needs to expand the system to support other CEs in different regions as well including social media towards story telling of micro-influencers which can affect the customer journey in most direct way, as a further distribution channel, in a broader system.

\section{Acknowledgements}

The authors gratefully acknowledge financial support from National Research Council of Thailand. The authors would like to express their gratitude to Mr. Michael Currie, from the Publication Clinic, Research and Development Office, Prince of Songkla University, for help in manuscript preparation. 


\section{Funding}

This work was supported by the National Research Council of Thailand under Grant RDG61T0050.

\section{References}

Ailawadi, K. L., \& Farris, P. W. (2017). Managing multi- and omni-channel distribution: metrics and research directions. Journal of Retailing, 93(1), 120-135. https://doi.org/10.1016/j.jretai.2016.12.003

Beck, N., \& Rygl, D. (2015). Categorization of multiple channel retailing in multi-, cross-, and omnichannel retailing for retailers and retailing. Journal of Retailing and Consumer Services, 27, 170-178. https://doi.org/10.1016/j.jretconser.2015.08.001

Bhatiasevi, V., \& Dutot, V. (2014). Creative industries and their role in the creative value chain - a comparative study of SMEs in Canada and Thailand. International Journal of Entrepreneurship and Innovation Management, 18(5-6), 466-480. https://doi.org/10.1504/IJEIM.2014.064721

Blázquez, M. (2014). Fashion shopping in multichannel retail: the role of technology in enhancing the customer experience. International Journal of Electronic Commerce, 18(4), 97-116. https://doi.org/10.2753/JEC1086-4415180404

Boccella, N., \& Salerno, I. (2016). Creative economy, cultural industries and local development. Procedia - Social and Behavioral Sciences, 223, 291-296. https://doi.org/10.1016/j.sbspro.2016.05.370

Brereton, P., Kitchenham, B. A., Budgen, D., Turner, M., \& Khalil, M. (2007). Lessons from applying the systematic literature review process within the software engineering domain. Journal of Systems and Software, 80(4), 571-583. https://doi.org/10.1016/j.jss.2006.07.009

Chai-Arayalert, S., \& Suttapong, K. (2018). Increasing the potential of distribution channels and creating new products from Thai weaving based on digital economy: case study in Southern Weaving community enterprise (RDG61T0050). National Research Council of Thailand.

Cook, G. (2014). Customer experience in the omni-channel world and the challenges and opportunities this presents. Journal of Direct, Data and Digital Marketing Practice, 15(4), 262-266. https://doi.org/10.1057/dddmp.2014.16

Depa. (2017). Thailand's digital economy at a grance. https://www.depa.or.th/en/article-view/thailand-digital-economy-glance

Dholakia, U. M., Kahn, B. E., Reeves, R., Rindfleisch, A., Stewart, D., \& Taylor, E. (2010). Consumer behavior in a multichannel, multimedia retailing environment. Journal of Interactive Marketing, 24(2), 86-95. https://doi.org/10.1016/j.intmar.2010.02.005

Distanont, A., Khongmalai, O., \& Distanont, S. (2019). Innovations in a social enterprise in Thailand. Kasetsart Journal of Social Sciences, 40(2), 411-419.

Fayaz, R., \& Azizinia, M. (2016). Current challenges in distribution channels of cultural goods and services. Marketing and Branding Research, 3(1), 75-85. https://doi.org/10.33844/mbr.2016.60219

Følstad, A., \& Kvale, K. (2018). Customer journeys: a systematic literature review. Journal of Service Theory and Practice, 28(2), 196-227. https://doi.org/10.1108/JSTP-11-2014-0261

Gallino, S., \& Moreno, A. (2014). Integration of online and offline channels in retail: the impact of sharing reliable inventory availability information. Management Science, 60(6), 1434-1451. https://doi.org/10.1287/mnsc.2014.1951

Hansen, R., \& Tambo, T. (2011, 16-19 August). Branding and channel issues in e-commerce from an information system perspective. In T. Leino (Ed.), Proceedings of IRIS 2011. Series: TUCS Lecture Notes. No. 15. The 34th Information Systems Research Seminar in Scandinavia. IRIS 2011 (pp. 200215). Turku, Finland. Turku Centre for Computer Science. 
Hasan, L., Morris, A., \& Probets, S. (2013). E-commerce websites for developing countries - a usability evaluation framework. Online Information Review, 37(2), 231-251. https://doi.org/10.1108/OIR-10-2011-0166

Herhausen, D., Binder, J., Schoegel, M., \& Herrmann, A. (2015). Integrating bricks with clicks: retailerlevel and channel-level outcomes of online-offline channel integration. Journal of Retailing, 91(2), 309-325. https://doi.org/10.1016/j.jretai.2014.12.009

Huang, Zh., \& Benyoucef, M. (2017). The effects of social commerce design on consumer purchase decision-making: an empirical study. Electronic Commerce Research and Applications, 25, 40-58. https://doi.org/10.1016/j.elerap.2017.08.003

Huré, E., Picot-Coupey, K., \& Ackermann, C.-L. (2017). Understanding omni-channel shopping value: a mixed-method study. Journal of Retailing and Consumer Services, 39, 314-330. https://doi.org/10.1016/j.jretconser.2017.08.011

Hübner, A., Holzapfel, A., \& Kuhn, H. (2016). Distribution systems in omni-channel retailing. Business Research, 9, 255-296. https://doi.org/10.1007/s40685-016-0034-7

Industry Network, Thailand Textile Institute. (2017). Thailand textile statistics. https://www.thaitextile. org/th/esan-inno-fabric/index.php

Ishfaq, R., Defee, C. C., Gibson, B. J., \& Raja, U. (2016). Realignment of the physical distribution process in omni-channel fulfillment. International Journal of Physical Distribution and Logistics Management, 46(6-7), 543-561. https://doi.org/10.1108/IJPDLM-02-2015-0032

Jabangwe, R., Edison, H., \& Nguyen Duc, A. (2018). Software engineering process models for mobile app development: a systematic literature review. Journal of Systems and Software, 145, 98-111. https://doi.org/10.1016/j.jss.2018.08.028

Jeffers, P. I., \& Nault, B. R. (2011). Why competition from a multi-channel e-tailer does not always benefit consumers. Decision Sciences, 42(1), 69-91. https://doi.org/10.1111/j.1540-5915.2010.00302.x

Karimi, S., Papamichail, K. N., \& Holland, Ch. P. (2014, May 29-31; July, 1-4). Purchase decision processes in the internet age. In F. Dargam, J. E. Hernández, P. Zaraté, Sh. Liu, R. Ribeiro, B. Delibašić, \& J. Papathanasiou (Eds.), Decision support systems iii - impact of decision support systems for global environments. Euro Working Group Workshops, EWG-DSS 2013 (pp. 57-66). Thessaloniki, Greece, and Rome, Italy. Revised, Selected and Extended Papers. Series: Lecture Notes in Business Information Processing. Vol. 184. W. van der Aalst, J. Mylopoulos, M. Rosemann, M. J. Shaw, \& C. Szyperski (Series Eds.). Springer International Publishing.

Kluge, Ph. N., \& Fassnacht, M. (2015). Selling luxury goods online: effects of online accessibility and price display. International Journal of Retail and Distribution Management, 43(10-11), 1065-1082. https://doi.org/10.1108/IJRDM-07-2014-0097

Lazaris, Ch., Vrechopoulos, A., Doukidis, G., \& Fraidaki, A. (2015, 3-5 October). Mobile apps for omnichannel retailing: revealing the emerging showrooming phenomenon. Proceedings of 9 th Mediterranean Conference on Information Systems (MCIS). 9th Mediterranean Conference on Information Systems (MCIS). Samos, Greece. https://pdfs.semanticscholar.org/6542/cce252dc67887eba4cfddb7c26cd0bb10d5b.pdf

Lemon, K. N., \& Verhoef, P. C. (2016). Understanding customer experience throughout the customer journey. Journal of Marketing, 80, 69-96. https://doi.org/10.1509/jm.15.0420

Lewis, J., Whysall, P., \& Foster, C. (2014). Drivers and technology-related obstacles in moving to multichannel retailing. International Journal of Electronic Commerce, 18(4), 43-68. https://doi.org/10.2753/JEC1086-4415180402

Magrath, V., \& McCormick, H. (2013). Branding design elements of mobile fashion retail apps. Journal of Fashion Marketing and Management, 17(1), 98-114. https://doi.org/10.1108/13612021311305164

Marquez, J. J., Downey, A., \& Clement, R. (2015). Walking a mile in the user's shoes: customer journey mapping as a method to understanding the user experience. Internet Reference Services Quarterly, 20(3-4), 135-150. https://doi.org/10.1080/10875301.2015.1107000 
McColl-Kennedy, J. R., Gustafsson, A., Jaakkola, E., Klaus, Ph., Radnor, Z. J., Perks, H., \& Friman, M. (2015). Fresh perspectives on customer experience. Journal of Services Marketing, 29(6-7), 430-435. https://doi.org/10.1108/JSM-01-2015-0054

Menon Vadakepat, V., \& Al Khateeb, F. (2012). Globalizing rural markets: evidence from handmade traditional product markets. Global Journal of Business Research, 6(4), 35-43.

Mirsch, T., Lehrer, Ch., \& Jung, R. (2016, 27 June-1 July). Channel integration towards omnichannel management: a literature review. Proceedings of 20th Pacific Asia Conference on Information Systems (PACIS). 20th Pacific Asia Conference on Information Systems (PACIS). Chiayi, Taiwan. https://www. alexandria.unisg.ch/248768/1/CHANNEL\%20INTEGRATION\%20TOWARDS\%20OMNICHANNEL\%20MANAGEMENT\%20A\%20LITERATURE\%20REVIEW.pdf

Neslin, S. A., \& Shankar, V. (2009). Key issues in multichannel customer management: current knowledge and future directions. Journal of Interactive Marketing, 23(1), 70-81. https://doi.org/10.1016/j.intmar.2008.10.005

Pantano, E., \& Viassone, M. (2015). Engaging consumers on new integrated multichannel retail settings: challenges for retailers. Journal of Retailing and Consumer Services, 25, 106-114. https://doi.org/10.1016/j.jretconser.2015.04.003

Parivudhiphongs, A. (2019). Creative industries policy in Thailand: A story of Rise and Demise. In L. Lim, \& H.-K. Lee (Eds.), Routledge handbook of cultural and creative industries in Asia (pp. 27-42). Series: Routledge Handbooks. Routledge. https://doi.org/10.4324/9781315660509-3

Parker, B., \& Weber, R. (2013). Second-hand spaces: restructuring retail geographies in an era of ecommerce. Urban Geography, 34(8), 1096-1118. https://doi.org/10.1080/02723638.2013.790642

Patichol, P., Wongsurawat, W., \& Johri, L. M. (2014). Upgrade strategies in the Thai Silk industry: balancing value promotion and cultural heritage. Journal of Fashion Marketing and Management, 18(1), 20-35. https://doi.org/10.1108/JFMM-09-2011-0059

Picot-Coupey, K., Huré, E., \& Piveteau, L. (2016). Channel design to enrich customers' shopping experiences: synchronizing clicks with bricks in an omni-channel perspective. The direct optic case. International Journal of Retail and Distribution Management, 44(3), 336-368. https://doi.org/10.1108/IJRDM-04-2015-0056

Piotrowicz, W., \& Cuthbertson, R. (2014). Introduction to the special issue information technology in retail: toward omnichannel retailing. International Journal of Electronic Commerce, 18(4), 5-16. https://doi.org/10.2753/JEC1086-4415180400

Rosenbaum, M. S., Losada Otalora, M., \& Contreras Ramírez, G. (2017). How to create a realistic customer journey map. Business Horizons, 60(1), 143-150. https://doi.org/10.1016/j.bushor.2016.09.010

Rossi, C. (2016). Craft and the creative economy. International Journal of Cultural Policy, 22(3), 473476. https://doi.org/10.1080/10286632.2015.1102907

Spence, Ch., Puccinelli, N. M., Grewal, D., \& Roggeveen, A. L. (2014). Store atmospherics: a multisensory perspective. Psychology and Marketing, 31(7), 472-488. https://doi.org/10.1002/mar.20709

Stefani, A., \& Xenos, M. (2011). Weight-modeling of B2C system quality. Computer Standards and Interfaces, 33(4), 411-421. https://doi.org/10.1016/j.csi.2011.01.002

Stein, A., \& Ramaseshan, B. (2016). Towards the identification of customer experience touch point elements. Journal of Retailing and Consumer Services, 30, 8-19. https://doi.org/10.1016/j.jretconser.2015.12.001

Thailand Board of Investment. (2018). Thailand's digital economy: setting the pace in ASEAN. Thailand Investment Review, 8(16). https://www.boi.go.th/upload/content/TIR September2018_5bbc1a2deb947.pdf

Vivek, Sh. D., Beatty, Sh. E., \& Morgan, R. M. (2012). Customer engagement: exploring customer relationships beyond purchase. Journal of Marketing Theory and Practice, 20(2), 122-146.

https://doi.org/10.2753/MTP1069-6679200201 
Wade Clarke, D., Perry, P., \& Denson, H. (2012). The sensory retail environment of small fashion boutiques. Journal of Fashion Marketing and Management, 16(4), 492-510. https://doi.org/10.1108/13612021211265872

Wechakama, Th. (2011). Folk art and handicraft: integrating creative economy for business community development in Northeast Thailand. European Journal of Social Sciences, 27(1), 82-95.

Wolny, J., \& Charoensuksai, N. (2014). Mapping customer journeys in multichannel decision-making. Journal of Direct, Data and Digital Marketing Practice, 15(4), 317-326. https://doi.org/10.1057/dddmp.2014.24

Wongleedee, K. (2015). Marketing mix and purchasing behavior for community products at traditional markets. Procedia - Social and Behavioral Sciences, 197, 2080-2085. https://doi.org/10.1016/j.sbspro.2015.07.323

Wuwei, L. (2011). How creativity is changing China. M. Keane (Ed.). Bloombury Academic.

Zhang, M., Ren, Ch., Wang, G. A., \& He, Zh. (2018). The impact of channel integration on consumer responses in omni-channel retailing: the mediating effect of consumer empowerment. Electronic Commerce Research and Applications, 28, 181-193. https://doi.org/10.1016/j.elerap.2018.02.002

\title{
TAILANDIETIŠKŲ RANKOMIS AUSTŲ KŪRYBINIŲ TEKSTILĖS PRODUKTŲ PLATINIMO KANALŲ GALIMYBIŲ DIDINIMAS SKAITMENINĖS EKONOMIKOS SĄLYGOMIS
}

\author{
Supaporn CHAI-ARAYALERT, Ketsaraporn SUTTAPONG \\ Santrauka
}

\begin{abstract}
Straipsnio tikslas - ištirti daugiakanalę platinimo sistemą, skirtą audejjų bendruomenès įmonems. Šis tyrimas yra kokybinis, ji atliekant buvo taikytas atvejo analizès metodas. Rezultatai ịvardija kūrybinių produktų pardavimo apribojimus vien fizinèse parduotuvèse, kuriose nèra galimybių patenkinti vartotojų apsipirkimo elgesio ịpročių ir poreikių. Vis dèlto rankomis austų produktų subtilumo skaitmeninių medijų sąlygomis internetu neįmanoma atskleisti, nes juos reikia paliesti ir padèvèti. Šis dichotomiškumas atvèrè kelią sistemos pirmosios versijos dizainui ir plètrai. Tyrimu skatinama audejjų bendruomenių i̇mones plèsti savąją rinką, siekiant konkuruoti skaitmeninès ekonomikos sąlygomis, pateikiama vertingų praktinių įžvalgų apie vietos audejų bendruomenių įmones ir jų galimybes parduoti savo kūrybinius produktus.

Šis tyrimas užpildo literatūros spragas, susijusias su vartotojo kelione ir platinimo kanalų integracija, išryškina vietos audejjų i̇monių poreiki prisitaikyti prie esamų rinkos sąlygų.
\end{abstract}

Reikšminiai žodžiai: bendruomenès įmonè, kūrybinis produktas, vartotojo kelionė, platinimo kanalas, rankų darbo tekstilè, daugiakanalè strategija. 